\title{
FOREIGN LANGUAGE COMPETENCE OF TEACHERS
}

\section{Olga Voloshina ${ }^{1}$}

${ }^{I}$ Ph.D. (Pedagogy), Methodist of the Laboratory of Monitoring Research of KZ "Kirovohrad Regional Institute of Postgraduate Pedagogical Education named after Vasyl Sukhomlynsky", Kropyvnytskyi, Ukraine, e-mail: mikka071986@gmail.com,ORCID: https://orcid.org/0000-0001-8226-8681

Abstract. This article considers the problem of connection between the foreign language communicative and professional competence of a teacher. The purpose of the article is to clarification of the level of the teacher's foreign language communicative competence is; determination of the main criteria and indicators that affect the level of the teacher's foreign language communicative competence. The research methodology includes the use of the following methods: mathematical and statistical methods of data, analysis. It has been established that professional competence is understood as the unity of his theoretical and practical readiness for professional activity, has a communicative orientation, characterizes a set of professionally important qualities and characteristics. It was found that foreign language communicative competence is a complex of knowledge, abilities and skills, as well as the experience of their use, which gives the teacher the opportunity to effectively and productively use a foreign language for professional activities. The level of foreign language communicative competence of teachers was clarified. It is proved that foreign language communicative competence is an important and integral part of the professional competence of a foreign language teacher.

Key words: professional competence, professional competence of a teacher, foreign language communicative competence, monitoring research.

JEL Classification: JEL I0; I20

Formulas: 3; fig.: 5; tabl.: 4; bibl.: 10

Introduction. The modernization of Ukrainian education and the implementation of the New Ukrainian School Concept is a synergistic long-term reform that directly affects less than $65 \%$ of the country's population, the most ambitious reform in the years of Ukraine's independence. We are not talking about a single influence, but the connection of the Ukrainian school with the family, society, personality of the child, its continuous development, from early preschool age to adult education.

The task of the teacher is to coordinate and direct the activities of students towards the formation of communicative and educational-cognitive needs, development of generalized methods and techniques of educational activity, formulation and independent solution of specific educational tasks (cognitive, research, transformative, project, etc.), assimilation of new knowledge, improvement skills in all types of activities.

The knowledge society development's model requires from a modern specialist a teacher with a wide range of skills and competencies for the successful fulfillment of their professional functions, ensuring the comprehensive and sustainable development of education and science in Ukraine. Continuous professional development of a teacher in a knowledge society is a kind of challenge to his informational parameters, a response to instability in the field of employment and professions.

These issues have particular importance for the higher pedagogical school, which is faced with the task of training future teachers of the appropriate profile, who 
were characterized by high professionalism and quality of professional activity. Taking this into account, the requirements for the semantic and organizationalmethodological content of the professional training of future teachers are increasing, basing this process on the basic ideas of the competence-based approach.

Literature review. A significant number of works by both foreign and domestic scientists are devoted to the problem of foreign language competence: $E$. Vereshchagin, I. Zimnyaya, V. Kostomarov, E. Passova, L. Shcherba.

The problems associated with the disclosure of the essence of the teacher's professional competence have become the subject of scientific research by $\mathrm{M}$. Zhaldak, M. Kornilova, L. Mitina, S. Molchanov, N. Nichkalo, S. Sysoeva.

Features of the formation and development of communicative competence are studied by N. Klyuev, V. Kunitsyna, N. Kazarinov, Yu. Turchaninova.

Aims. The purpose of the article is to clarification of the level of the teacher's foreign language communicative competence is; determination of the main criteria and indicators that affect the level of the teacher's foreign language communicative competence.

Methods. The research methodology includes the use of the following methods: mathematical and statistical methods of data, analysis.

Results. Foreign language competence has its particular importance due to the fact that the education system is currently characterized by significant innovative transformations. In the current conditions, in order to be successful and in demand, a teacher must be ready for any changes, be able to quickly and effectively adapt to new conditions, show the desire to be a professional, constantly update their knowledge and skills, strive for self-development, show tolerance for uncertainty, be ready to risk, that is, another words - be professionally competent.

However, as social practice shows, these characteristics are not formed in all teachers. On the contrary, a significant part of them experience great difficulties in adapting to rapidly changing social, economic, professional conditions, and then the lack of professional competence can cause serious social and psychological problems of the individual - from internal dissatisfaction to social confrontation and aggression.

The success of the development of foreign language education, in turn, is largely determined by the readiness of professional personnel working in the field of education to work in an innovative mode, to be flexible and responsive in their professional activities to the constantly changing needs of society and individuals. Therefore, the development of professional foreign language competence of teachers is becoming one of the most important conditions for reforming education.

Competence, as a scientific problem, currently does not yet have an accurate and unambiguous definition and has not received a comprehensive analysis, despite the fact that interest in it has a significant history of development.

Currently, the concept of «competence» includes not only cognitive and technological components, but also motivational, ethical, social and behavioral. As well as learning outcomes (knowledge and skills), a system of value orientations, habits. 
The purpose of education is the formation of foreign language communicative competence for direct and indirect intercultural communication. Foreign language communicative competence - is the ability and willingness to act as a secondary linguistic personality in various communication situations, that is, to participate in intercultural communication.

Conducting this monitoring study is one of the ways to implement the state policy in the field of teacher training, which is to activate the work of teachers in the direction of ensuring the implementation of new state standards and the right of students to receive a quality education.

The total number of respondents who participated in the study is 2257 people (Table 1).

Table 1

Sample of survey respondents

\begin{tabular}{|l|l|c|}
\hline № & \multicolumn{1}{|c|}{ Name of district / city } & Number of teachers \\
\hline 1 & Blagovishchenskyi & 81 \\
\hline 2 & Bobrynetskyi & 82 \\
\hline 3 & Vilshanskyi & 49 \\
\hline 4 & Gaivoronskyi & 101 \\
\hline 5 & Golovanivskyi & 93 \\
\hline 6 & Dobrovelychkivskyi & 65 \\
\hline 7 & Dolynskyi & 89 \\
\hline 8 & Znamyanskyi & 74 \\
\hline 9 & Kropyvnytskyi & 53 \\
\hline 10 & Kompaniivskyi & 61 \\
\hline 11 & Malovyskivskyi & 56 \\
\hline 12 & Novgorodkivskyi & 51 \\
\hline 13 & Novoarkhangelskyi & 87 \\
\hline 14 & Novomyrhorodskyi & 89 \\
\hline 15 & Novoukrainskyi & 65 \\
\hline 16 & Olexandrivskyi & 93 \\
\hline 17 & Olexandriyskyi & 105 \\
\hline 18 & Onufriyivskyi & 66 \\
\hline 19 & Petrivskyi & 60 \\
\hline 20 & Svitlovodskyi & 43 \\
\hline 21 & Ustynivskyi & 47 \\
\hline 22 & t. Znamyanka & 61 \\
\hline 23 & t. Olexandria & 172 \\
\hline 24 & t. Svitlovodsk & 77 \\
\hline 25 & t. Kropyvnytskyi & 437 \\
\hline TOTAL: & $\mathbf{2 2 5 7}$ \\
\hline & & \\
\hline
\end{tabular}

A comparative analysis of the results of a monitoring study of the foreign language communicative competence of teachers in the Kirovograd region showed that among primary school teachers working in institutions of the region, specialists of I and higher categories predominate ( $22.8 \%$ and $41 \%$, respectively). 


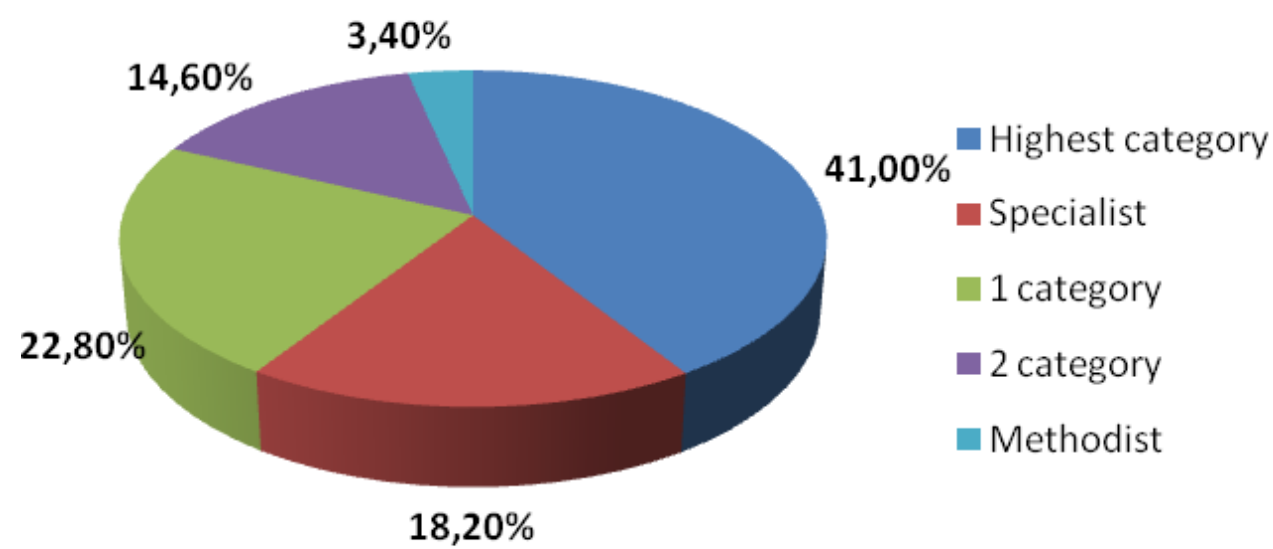

Fig. 1. Category of teachers

The teaching experience of the majority of the respondents is quite significant. Thus, $79.4 \%$ of teachers who participated in the monitoring study have more than 10 years of work experience.

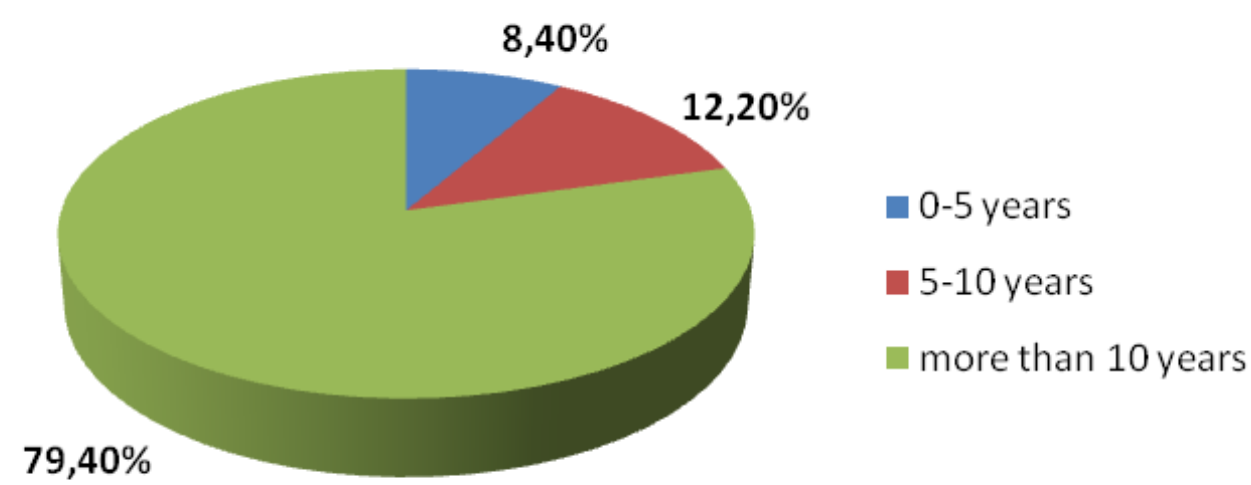

Fig.2 Pedagogical experience of teachers

Analysis of the respondents' answers showed that only $9.2 \%$ of teachers have a specialty «Primary Education and a Foreign Language», which means they have the right to teach a foreign language in primary grades in the conditions of the «New Ukrainian School». Most of the interviewed teachers have a specialty «Primary education». 


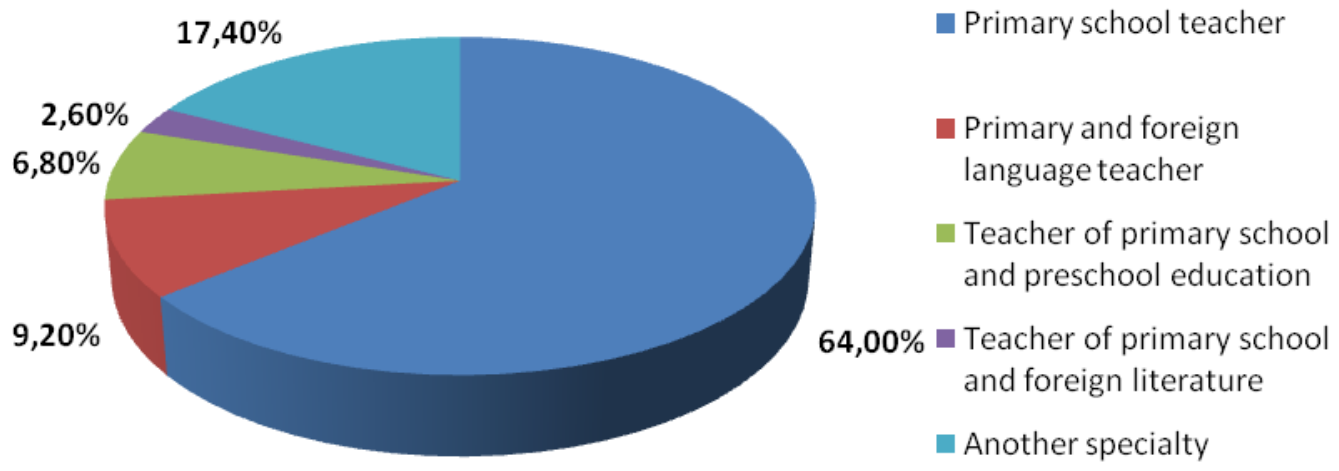

Fig.3. Specialty

According to the results of the study, we can say that a third of the respondents are guided in a foreign language communicative situation, as they are not specialists in this area.

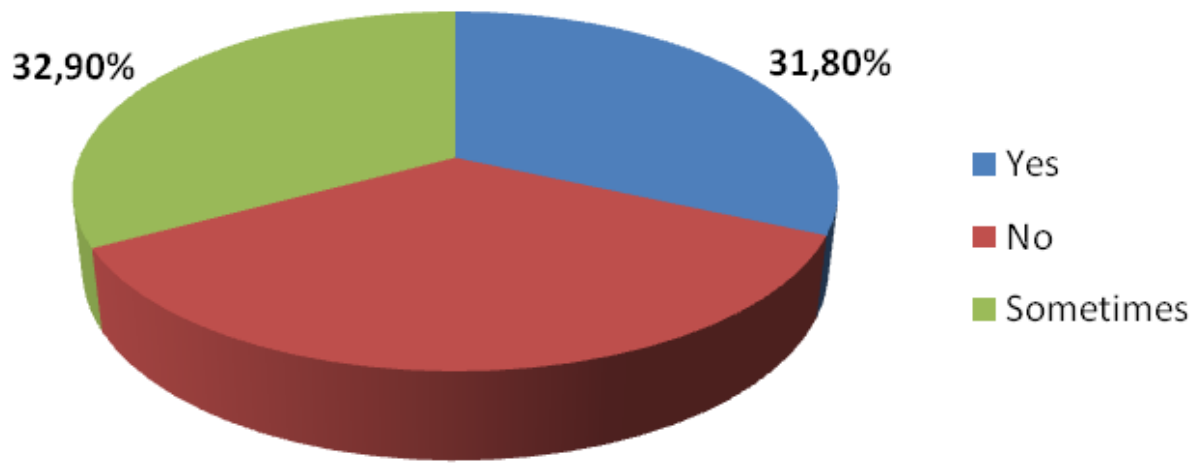

$35,30 \%$

\section{Fig.4. Orientation in a foreign language communicative situation}

Some teachers of the region need methodological help, self-education, in order to enrich their vocabulary.

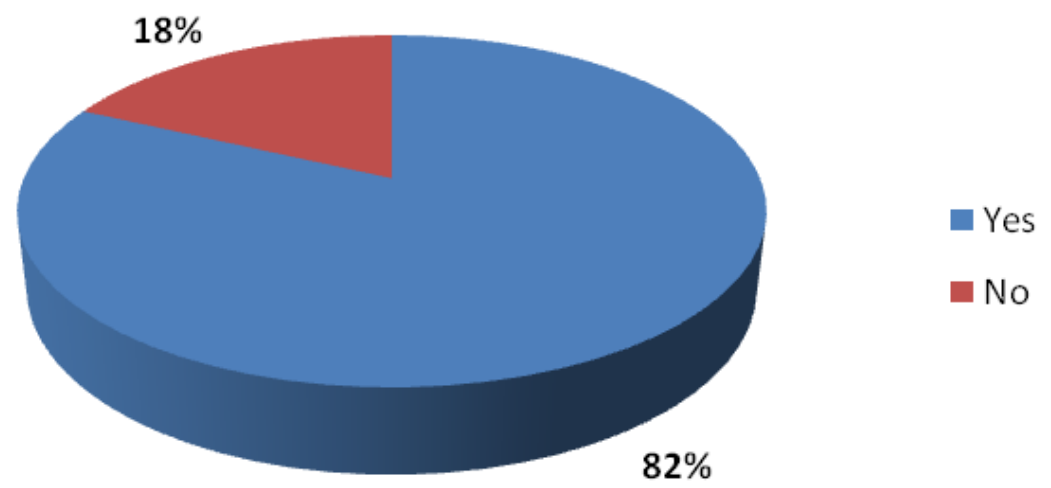

\section{Fig.5. Lexical stock}

To carry out mathematical calculations in order to bring the validity of the obtained results, the assessment is carried out in accordance with the scale, which is presented in Table 2. 
Table 2

Scale for assessing the levels of formation of foreign language competence of teachers

\begin{tabular}{|l|c|c|}
\hline Test tasks (points) & Score on a national scale & Level \\
\hline $90-100$ & Perfectly & High \\
\hline $75-89$ & Fine & Average \\
\hline $60-74$ & Satisfactorily & Low \\
\hline $35-59$ & Unsatisfactorily & \\
\hline
\end{tabular}

The results of the survey of teachers at the end of the study on the level of formation of foreign language competence are presented in Table 3.

Table 3

Numerical indicators of the levels of formation of foreign language competence of teachers after the experiment

\begin{tabular}{|l|c|c|c|c|c|}
\hline \multirow{2}{*}{ Levels of formation } & \multicolumn{2}{|c|}{ EG } & \multicolumn{2}{c|}{ CG } & Difference \\
\cline { 2 - 5 } & persons & $\%$ & persons & $\%$ & $\%$ \\
\hline High & 360 & 31,9 & 351 & 31,2 & 0,7 \\
\hline Average & 297 & 26,3 & 306 & 27,1 & $-0,8$ \\
\hline Low & 472 & 41,8 & 471 & 41,7 & 0,1 \\
\hline Together & 1129 & & 1128 & & \\
\hline
\end{tabular}

To determine the statistical reliability of the differences in the indicators of the levels of foreign language competence of teachers, we calculate the Student's tcriterion based on the data in Table 3 using the formula:

$$
S_{d}={\sqrt{S_{x}^{2}+S_{y}^{2}}}^{{ }^{2}}
$$

where $\bar{X}$ and $Y$ is the arithmetic mean of EG and $C G ; S d$ - standard deviation, which is calculated by the formula:

$$
S_{d}=\sqrt{S_{x}{ }^{2}+S_{y}{ }^{2}}=\sqrt{\frac{\Sigma\left(x_{i}-\bar{x}\right)^{2}+\Sigma\left(y_{i}-\bar{y}\right)^{2}}{\left(n_{1}+n_{2}-2\right)} \cdot \frac{\left(n_{1}+n_{2}\right)}{\left(n_{1} \cdot n_{2}\right)}}
$$

where $n_{1}$ and $n_{2}$ are the sample sizes in $E G$ and $C G ; n_{-}(1) \neq n_{-} 2$,

$$
\sum\left(x_{i}-\bar{x}\right)^{2} \text { and } \sum\left(y_{i}-\bar{y}\right)^{2} \text { are standard deviations. }
$$

Calculation of the number of degrees of freedom:

$$
k=\left(n_{1}-1\right)+\left(n_{2}-1\right)=n_{1}+n_{2}-2
$$

Comparative data indicate the mediocre formation of the foreign language competence of teachers in the region.

As for the teachers of the control group, according to the relevant criteria, we note a slight positive trend. 
Table 4

Qualitative assessment of the results of the formation of foreign language competence of teachers after the experiment

\begin{tabular}{|l|c|c|c|c|c|c|}
\hline \multirow{2}{*}{$\begin{array}{c}\text { Indicators of } \\
\text { criteria }\end{array}$} & \multicolumn{5}{|c|}{ Dynamics of levels of formation of indicators, \% } \\
\cline { 2 - 7 } & \multicolumn{4}{|c|}{ EG } & \multicolumn{4}{c|}{ CG } \\
\cline { 2 - 7 } & high & medium & low & high & medium & low \\
\hline Motivational & 3 & 4 & 1 & 2 & 6 & 8 \\
\hline Semantic & 27 & 15 & 12 & 6 & 0 & 6 \\
\hline Procedural & 14 & 13 & 1 & 10 & 2 & 12 \\
\hline
\end{tabular}

A monitoring study of the foreign language communicative competence of teachers in the Kirovograd region revealed a number of problems:

- Some teachers require counseling on how to establish contact with students;

- Increasing self-esteem and confidence in teaching in primary grades;

- Improving the pedagogical skills of teachers;

- Enrichment of vocabulary;

- Pay attention to politeness and correctness in relation to students;

- Taking into account the age characteristics of students.

Conclusion. The knowledge society development's model requires from a modern specialist, teacher a wide range of skills and competencies for the successful fulfillment of their professional functions, ensuring the comprehensive and sustainable development of education and science in Ukraine. One of these competencies is foreign language. According to the results of the monitoring research, it can be argued that more than $60 \%$ of the surveyed respondents navigate in a foreign language communicative situation.

The study showed that the Ukrainian school requires new approaches to teaching based on the principles of partnership pedagogy, cooperation between students and teachers, abandonment of an authoritarian model of communication, requires a rethinking of the role of both the teacher and the student.

For the purposes of the Ukrainian school, the main tasks of the formation of the pedagogical competence of a specialist are specified:

- to ensure mastery of technologies of self-organization and self-actualization;

- create conditions for the formation of a professional culture of a specialist;

- to intensify the formation of key competencies of the teacher;

- to form professional mobility;

- organize methodological and didactic support for the teacher;

- to form social activity based on the personality traits and social skills of the individual.

A teacher's foreign language communicative competence is:

- possession of systemic knowledge about the norms and types of pedagogical communication in the process of organizing collective and individual activities;

- the ability to listen, defend one's position using various methods of reasoning and argumentation;

- development of a culture of professional communication; 
- the ability to achieve pedagogical results by means of productive communicative interaction (relevant knowledge, verbal and non-verbal skills and abilities, depending on the communicative and activity situations).

The communicative competence of the teacher, the skill of business and interpersonal communication is a necessary tool for the humanization of education. High results in educational and pedagogical activity can be achieved only by the teacher who knows how to establish good relations with pupils, parents, who is inherent in the ability to understand another, to direct the communication process to achieve pedagogical tasks.

\section{References:}

1. Bulakh, I. (2006), Stvoryuyemo yakisnyy test [We create a quality test], K.: UDPU, 160 p. [in Ukrainian].

2. Voloshina, O. (2018), Teacher trainang for the use of test technologies in English in the initial classes, Monografia pokonferencyjna. Science, research, development. Pedagogy, Warszawa, No 6, pp. 47-50. [in English].

3. Gavrilyuk, A. (2017), Zastosuvannya komunikatyvnoho metodu vykladannya inozemnykh mov u vyshchykh navchal'nykh zakladakh [Application of the communicative method of teaching foreign languages in universities]

[Electronic resource], Mode of access to the resource: http://confesp.fl.kpi.ua/sites/default/files/onlayn_tezi_gavrilyuk.p df. [in Ukrainian].

4. Derzhavnyy standart pochatkovoyi osvity [State standard of primary education] (2018), ZATVERDZHENO postanovoyu Kabinetu Ministriv Ukrayiny vid 21 lyutoho $2018 \mathrm{r}$ No 87) [Electronic resource], Mode of access to the resource: https://ru.osvita.ua/legislation/Ser osv/59891/. [in Ukrainian].

5. Morozova, T. (2007), Diahnostyka uspishnosti uchytelya [Diagnosis of teacher success] Lutsk, 160p. [in Ukrainian].

6. Zhuk, Yu. Orhanizatsiya navchal'noyi diyal'nosti u komp'yuterno-oriyentovanomu navchalnomu seredovyshchi [Organization of educational activity in a computer-oriented learning environment], (2005), Kyiv, 453 p. [in Ukrainian].

7. Ivlieva, O. Kryterial'no-oriyentovane testuvannya $v$ systemi formuvannya profesiynoyi hotovnosti vchytelya pochatkovykh klasiv [Criteria-oriented testing in the system of formation of professional readiness of primary school teachers], (2001) author's ref. dis. for science. degree of Cand. ped. Science: 13.00.04., Izmail, 33 p. [in Ukrainian].

8. Kostikova, I. Podgotovka uchitelya inostrannogo yazyka: metodicheskiye osnovy informatsionnokommunikatsionnykh tekhnologiy [Preparation of a foreign language teacher: methodical bases of information and communication technologies] (2008), Kharkiv, 100 p. [in Russian].

9. Kravchenko, G. Yakist' osvity v navchal'nomu zakladi [Quality of education in an educational institution], (2013), Kharkiv, 176 p. [in Ukrainian].

10. Lysevych, O. Metodychni rekomendatsiyi shchodo formuvannya kul'tury pedahohichnoho spilkuvannya maybutnikh vchyteliv zasobamy dialohichnykh navchal'nykh sytuatsiy [Methodical recommendations for the formation of a culture of pedagogical communication of future teachers by means of dialogical educational situations], (2011), Kryvyi Rih, 30 p. [in Ukrainian]. 